\title{
Asiatic acid attenuates malignancy of human metastatic ovarian cancer cells via inhibition of epithelial-to- mesenchymal transition
}

\author{
Xiufen Wang, Jie Sun, Feifei Liu, Yinghui Bian, Lili Miao, Xinbo Wang* \\ Department of Gynaecology, Linzi District People's Hospital, Zibo, Shandong, 255400, PR China \\ *For correspondence: Email: xboowang@126.com
}

Sent for review: 14 March 2017

Revised accepted: 21 May 2017

\begin{abstract}
Purpose: To investigate the anticancer effects of asiatic acid on human metastatic ovarian cancer cells. Methods: Human metastatic ovarian cancer cell line SKOV-3 was treated with various concentrations of asiatic acid for 24 and $48 \mathrm{~h}$. Cell proliferation, migration, invasion and morphology were analyzed by CCK-8, Transwell and immunofluorescence assays, respectively. Epithelial-to-mesenchymal transitionrelated gene and protein expressions were analyzed by quantitative polymerase chain reaction ( $q P C R$ ) and Western blotting.

Results: Asiatic acid (10 $\mu$ M) significantly suppressed SKOV-3 cell migration and invasion (both $p<$ 0.01). Moreover, epithelial markers (E-cad and KRT-7/14/19) were elevated, while mesenchymal markers (vimetin, $N$-cad and ZEB1/2) were suppressed after asiatic acid treatment, at both mRNA and protein levels. Inhibition of epithelial-to-mesenchymal transition was further evidenced by immunofluorescence staining of pan-cytokeratin and F-actin.

Conclusion: Asiatic acid attenuates the malignancy of human metastatic ovarian cancer cells via epithelial-to-mesenchymal transition inhibition, and thus, is a therapeutic agent for ovarian cancer management.
\end{abstract}

Keywords: Asiatic acid, Ovarian cancer, Metastasis, Epithelial-to-mesenchymal transition, Vometin

Tropical Journal of Pharmaceutical Research is indexed by Science Citation Index (SciSearch), Scopus, International Pharmaceutical Abstract, Chemical Abstracts, Embase, Index Copernicus, EBSCO, African Index Medicus, JournalSeek, Journal Citation Reports/Science Edition, Directory of Open Access Journals (DOAJ), African Journal Online, Bioline International, Open-J-Gate and Pharmacy Abstracts

\section{INTRODUCTION}

Ovarian cancer is a deadly disease accounting for $3 \%$ of cancer while $5 \%$ of cancer-related death primarily in post-menopausal women [1]. With the introduction of cis-platinum and later paclitaxel together with debulking surgery, the cure rate of localized ovarian cancer reached 88 $\%$. However, nearly $65 \%$ of patients presented distant ovarian cancer at diagnosis with a dismal 12 -year survival rate of $18 \%$ [2]. Although novel targeted agents such as bevacizumab and olaparib have been applied for ovarian cancer treatment, only improved progression-free survival but not overall survival was observed $[3,4]$. Thus, there is still an urgent need to find new agents and develop novel therapeutic approaches in ovarian cancer treatment.

Asiatic acid $(A A)$, derived from an annual tropical herb Centella asiatica, is a pentacyclic triterpenoid medicinal compound with various pharmacological effects. Growth suppressive and pro-apoptotic effects of AA have been reported on several cancer cell lines including colon cancer [5], breast cancer [6], melanoma [7], glioblastoma [8,9], multiple myeloma [10] and hepatoma [11]. Moreover, the anticancer potential of $A A$ on ovarian cancer has also been 
investigated recently [12]. However, the effect of $A A$ on the migration and invasion of ovarian cancer cells has never been explored. Therefore, the present study was undertaken to investigate the anticancer potential of $A A$ on moremetastatic SKOV-3 human ovarian cancer cell line, with special focus on cell migration and invasion.

\section{EXPERIMENTAL}

\section{Chemicals and regents}

AA $\left(\mathrm{C}_{30} \mathrm{H}_{48} \mathrm{O}_{5}, \mathrm{MW}: 488.70\right.$, purity $\left.\geq 98 \%\right)$ was purchased from Biopurify Phytochemicals Litd. (Chengdu, China). Dimethyl sulfoxide (DMSO), streptomycin and penicillin were all products of Sigma-Aldrich (St. Louis, MO, USA).

\section{Cell culture}

Human metastatic ovarian cancer cell line SKOV-3 was obtained from ATCC (Manassas, VA, USA). Cells were cultured in DMEM (Gibco, Grand Island, NY, USA) supplemented with $10 \%$ fetal bovine serum (Gibco), $100 \mu \mathrm{g} / \mathrm{mL}$ streptomycin and $100 \mathrm{U} / \mathrm{mL}$ penicillin at $37^{\circ} \mathrm{C}$ with $5 \% \mathrm{CO}_{2}$. AA was dissolved in DMSO and stored at $-20{ }^{\circ} \mathrm{C}$, and diluted with DMEM to final concentrations when needed.

\section{Cell viability assay}

SKOV-3 cells $\left(5 \times 10^{3}\right.$ cells/well) seeded in 96-well plates were exposed to AA $(1,3,10$ and $30 \mu \mathrm{M})$ for 24 and $48 \mathrm{~h}$, respectively. Cell viability was determined by cell counting kit-8 (CCK-8, Dojindo, Tokyo, Japan) according to manufacturer's protocol. The absorbance (450 $\mathrm{nm}$ ) was determined by a Multiskan Spectrum reader (Thermo Scientific, Boston, MA, USA).

\section{Cell migration assay}

SKOV-3 cells $\left(1 \times 10^{5}\right.$ cells/well) were inoculated onto the upper chamber of the Transwell insert. After incubation for $24 \mathrm{~h}$ with $\mathrm{AA}$ (1, 3 and 10 $\mu \mathrm{M})$, migrated SKOV-3 cells on the lower side of the membrane were fixed with $4 \%$ formalin and were further stained with crystal violet. The migrated cells were counted in five random fields under microscope.

\section{Cell invasion assay}

The cell invasion assay was performed similar to cell migration assay, with Matrigel (BD Bioscience, Bedford, MA, USA) coated Transwell insert and incubation with $\mathrm{AA}(1,3$ and $10 \mu \mathrm{M})$ for $48 \mathrm{~h}$. Cells migrated across the Matrigel were stained and counted as described above.

\section{Immunofluorescence}

The immunofluorescence staining was performed as described previously [13]. In brief, after incubation with AA $(10 \mu \mathrm{M})$ for $48 \mathrm{~h}$, SKOV-3 cells were stained with anti-pan-cytokeratin antibody (Biolegend, San Diego, CA, USA) and phalloidin, and followed by incubation with AlexaFluor-488-conjugated secondary antibody (Invitrogen, Carlsbad, CA, USA). Sections were further sealed with Vectashield (Roche Diagnostics, Mannheim, Germany) containing DAPI and were observed under fluorescence microscope (Olympus, Tokyo, Japan).

\section{Quantitative polymerase chain reaction (qPCR) assay}

SsoFast EvaGreen Supermix (Bio-Rad, Hercules, CA, USA) were utilized to perform qPCR. Primers were obtained from Sangon Biotech (Shanghai, China) and were listed in Table. The expression of target genes was analyzed by $2^{-\Delta \Delta \mathrm{Ct}}$ method to determine the fold change.

\section{Western blot assay}

Western blot was conducted as previously described ${ }^{[14]}$ with specific primary antibodies for vimentin, $\mathrm{N}$-cadherin, zinc finger $\mathrm{E}$-box-binding homeobox 1 (ZEB1), ZEB2, E-cadherin, keratin 7

Table 1: Primer sequences

\begin{tabular}{lll}
\hline Target gene & Forward primer 5'-3' & Reverse primer 5'-3' \\
\hline Vimentin & AAA GTG TGG CTG CCA AGA AC & AGC CTC AGA GAG GTC AGC AA \\
N-cadherin & CGC CAT CAT CGC TAT CCT TCT GTG & AGC CGC TGC CCT CGT AGT CAA A \\
ZEB1 & AGA CTA TTC TGA TTC CCC AAG TG & CCT TCT GAG CTA GTG TCT TGT C \\
ZEB2 & GCC TTG AGT GCT CGA TAA GG & TTC CTG GGC TAC GAC CAT AC \\
E-cadherin & GAG CCT GAG TCC TGC AGT CC & GTA TTG CTG CTT GGC CTC A \\
KRT7 & CGA CAA CGG CTC CGG CAT GT & TGC CGT GCT CGA TGG GGT ACT \\
KRT14 & CCA GTT CTC CTC TGG ATC GCA G & GAT CTT CCA GTG GGA TCT GTG TCC A \\
KRT19 & TCC CAG CTC AGC ATG AAA GCT & AAA ACC GCT GAT CAC GCT CTG \\
$\beta$-Actin & CCA ACC GCG AGA AGA TGA & TCC ATC ACG ATG CCA GTG
\end{tabular}

$Z E B=$ zinc finger E-box-binding homeobox; $K R T=$ keratin 
(KRT7), KRT14, KRT19 and $\beta$-actin (Cell Signaling Technology, Beverly, MA, USA). The optical density of each protein band was determined by Image $\mathrm{J}$ (US NIH, Bethesda, MD, USA).

\section{Statistical analysis}

All studies were performed in quadruplicate and are reported as mean $\pm S D$. Statistical analysis was performed using one-way ANOVA followed by Dunnett's test, with $p<0.05$ considered as statistically significant. All calculations were performed using Prism (GraphPad Software Inc 7.0., La Jolla, CA, USA).

\section{RESULTS}

\section{Effect of AA on cell growth}

SKOV-3 cells were exposed to various concentrations of $\mathrm{AA}(1,3,10$ and $30 \mu \mathrm{M})$ for 24 and $48 \mathrm{~h}$, respectively. Cell growth was determined by CCK-8 assay. As shown in Figure

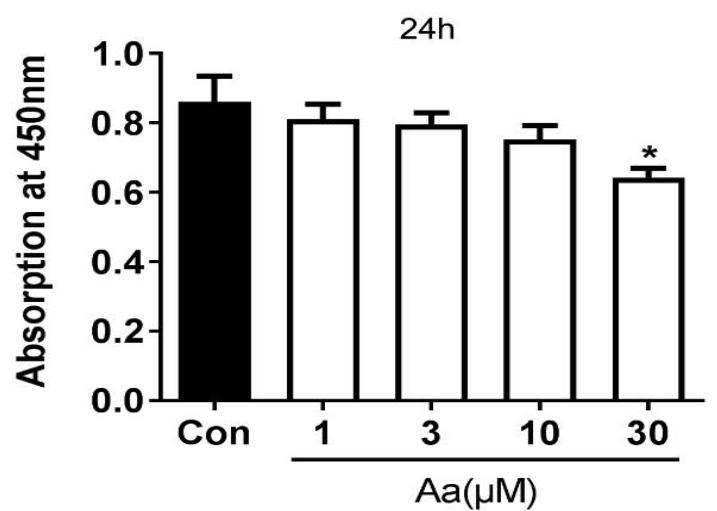

1, only $A A(30 \mu M)$ significantly inhibited cell growth at both 24 and $48 \mathrm{~h}$ (both $p<0.01$ ). Therefore, further studies were conducted using AA $(1,3$ and $10 \mu \mathrm{M})$ to avoid its cytotoxicity and pro-apoptotic effect, which have been reported in previous research [12].

\section{Effect of AA on cell migration}

SKOV-3 cells were inoculated into the upper chamber of the Transwell insert and further incubated with various concentrations of $A A(1,3$ and $10 \mu \mathrm{M}$ ) for $24 \mathrm{~h}$. As shown in Figure 2, AA $(10 \mu \mathrm{M})$ could significantly inhibited SKOV-3 cell migration across the membrane $(P<0.01)$, compared to the control group.

\section{Effect of AA on cell invasion}

SKOV-3 cells were inoculated into the upper chamber of the Transwell insert pre-coated with Matrigel. After $48 \mathrm{~h}$ incubation with AA (1, 3 and $10 \mu \mathrm{M})$,

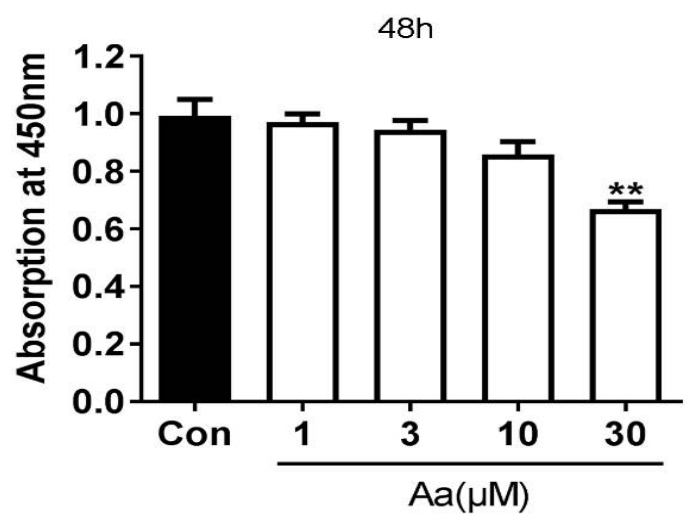

Figure 1: Effect of $A A$ on cell growth. Cells were incubated with various concentrations of AA for 24 and 48 h. Note: $\mathrm{AA}=$ asiatic acid; Con $=$ control group; ${ }^{*} p<0.05,{ }^{\star *} p<0.01$

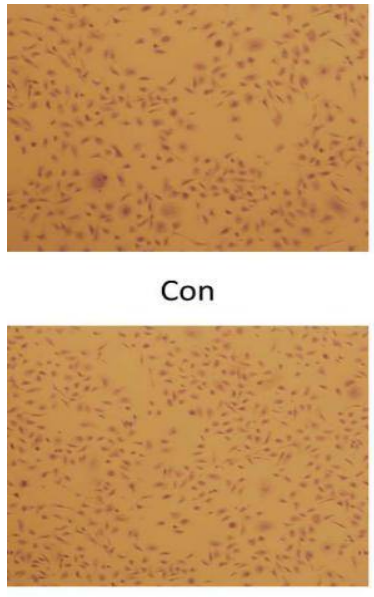

$\mathrm{AA}(3 \mu \mathrm{M})$

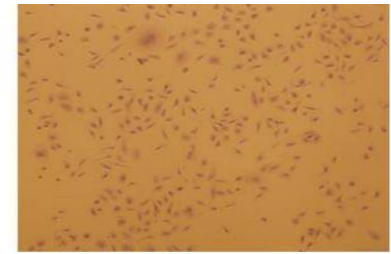

AA $(1 \mu \mathrm{M})$

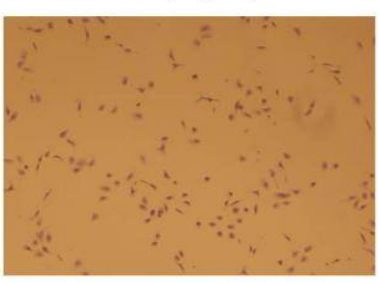

AA $(10 \mu \mathrm{M})$

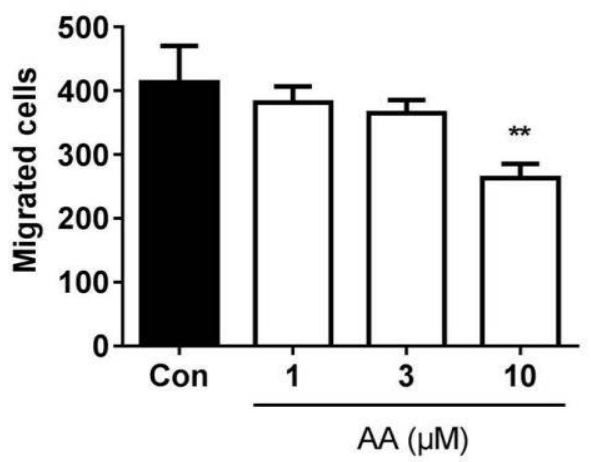

Figure 2: Effect of $A A$ on cell migration. Cells were incubated with various concentrations of $A A$ for $24 \mathrm{~h}$. Migrated cells were stained with crystal violet and counted in five random fields. Note: $A A=$ asiatic acid; Con = control group; ${ }^{* *} p<0.01$ 
there was a concentration-dependent decrease on invaded cell number. However, only AA (10 $\mu \mathrm{M})$ significantly suppressed SKOV-3 cell invasion, which is similar to previous cell migration results $(P<0.01$, Figure 3$)$.

\section{Effect of AA on epithelial-to-mesenchymal transition (EMT)}

As shown in Figure 4, SKOV-3 cell in the control group exhibited a more mesenchymal phenotype with elongated morphology and F-actin stain (red), which suggested an EMT was taking place. However, after incubation with AA $(10 \mu \mathrm{M})$ for 48 $h$, EMT was greatly inhibited as cells were of a

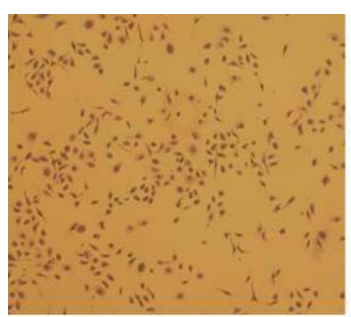

Con

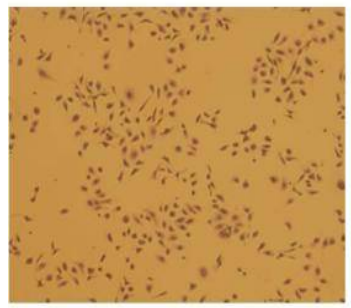

$\mathrm{AA}(3 \mu \mathrm{M})$

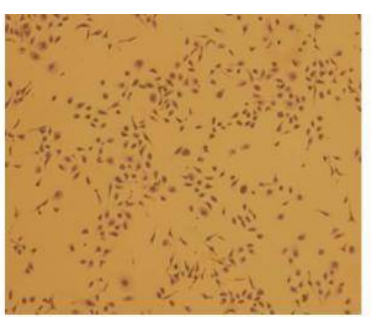

$\mathrm{AA}(1 \mu \mathrm{M})$

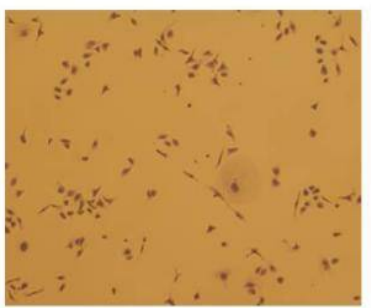

$\mathrm{AA}(10 \mu \mathrm{M})$

round morphology with wide range stain of cytokeratin (green).

\section{Effect of AA on EMT-related mRNAs expression}

EMT-related mRNAs expression was verified via qPCR assay. As shown in Figure 5, mesenchymal markers including vimentin, $\mathrm{N}$ cadherin, ZEB1 and ZEB2 were significantly decreased after AA treatment (at $10 \mu \mathrm{M}, p<$ $0.01, p<0.05, p<0.05$ and $p<0.01$, respectively), while epithelial markers involving E-cadherin, KRT7, KRT14 and KRT19 were significantly elevated (at $10 \mu \mathrm{M}, p<0.01, p<$ $0.05, p<0.05$ and $p<0.05$, respectively).

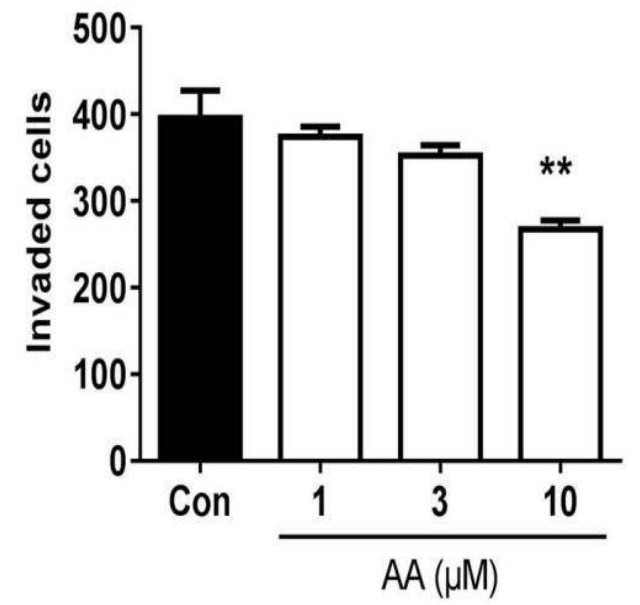

Figure 3: Effect of AA on cell invasion. Cells were incubated with various concentrations of AA for $48 \mathrm{~h}$. Invaded cells were stained with crystal violet and counted in five random fields. Note: $A A=$ asiatic acid; Con = control group; ${ }^{* *} p<0.01$

Pan-cytokeratin
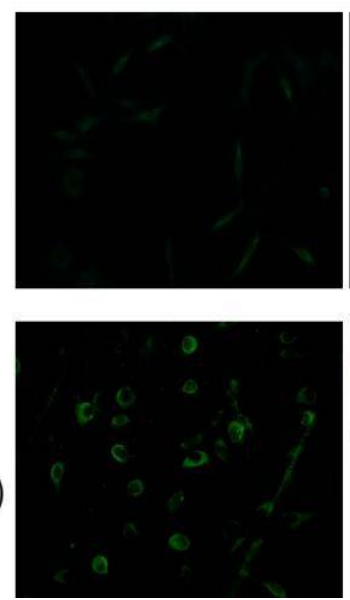

F-actin
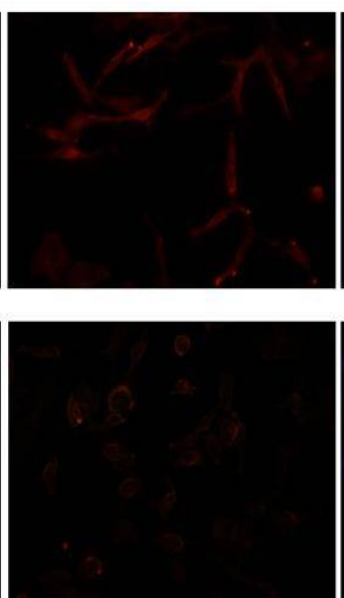

DAPI
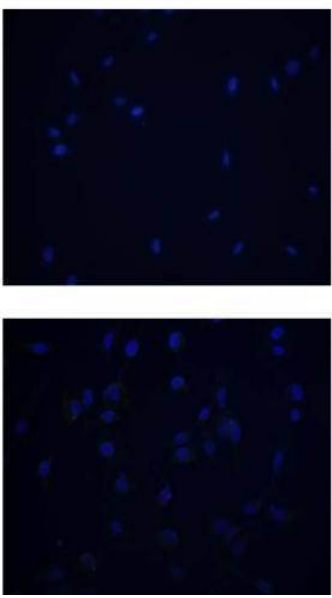

Merged
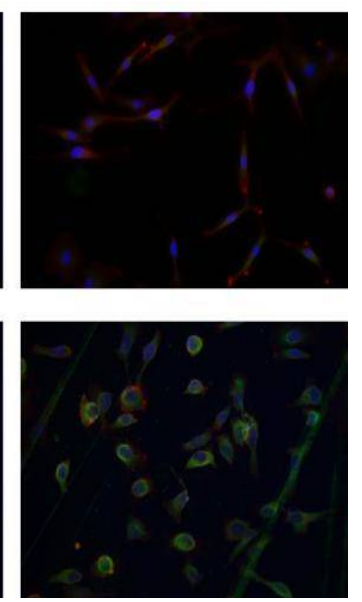

Figure 4: Effect of AA on epithelial-to-mesenchymal transition. Cells were treated with $A A(10 \mu M)$ for $48 \mathrm{~h}$ and were further stained with anti-pan-cytokeratin antibody (green) and phalloidin (red). Note: AA asiatic acid; Con = control group 

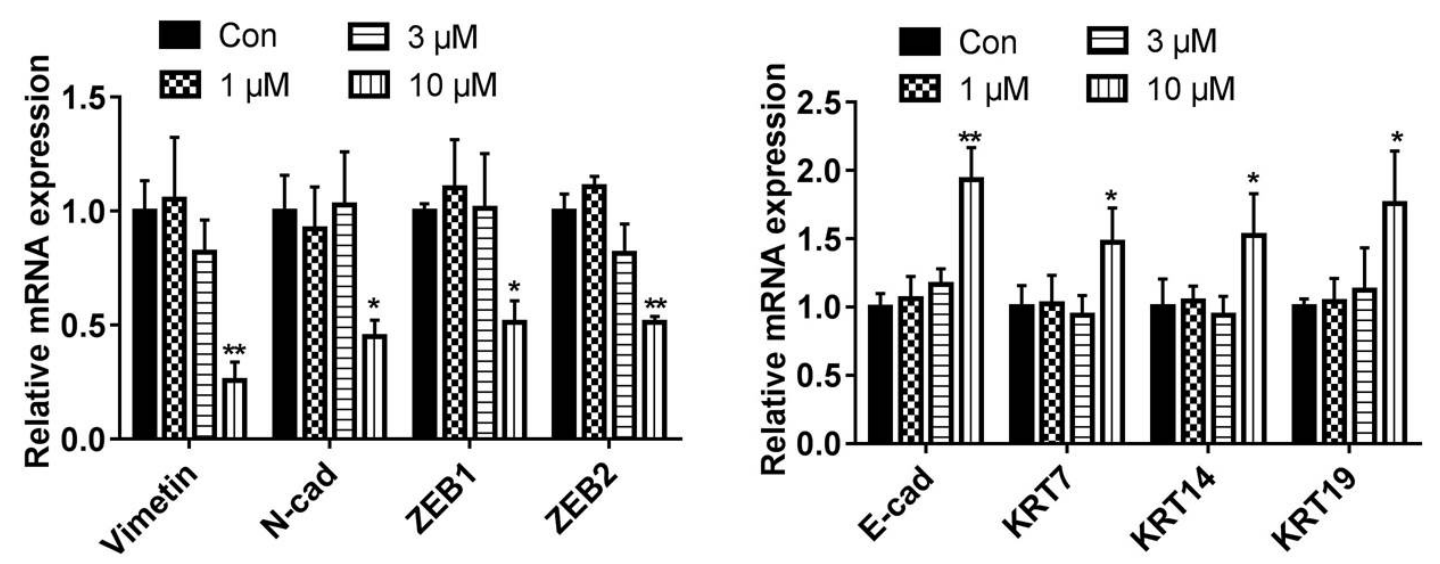

Figure 5: Effect of AA on EMT-related mRNAs expression. The relative fold change was determined by $2^{-\Delta \Delta \mathrm{Ct}}$ method. Note: Con $=$ control group; ${ }^{*} p<0.05 ;{ }^{* *} p<0.01$
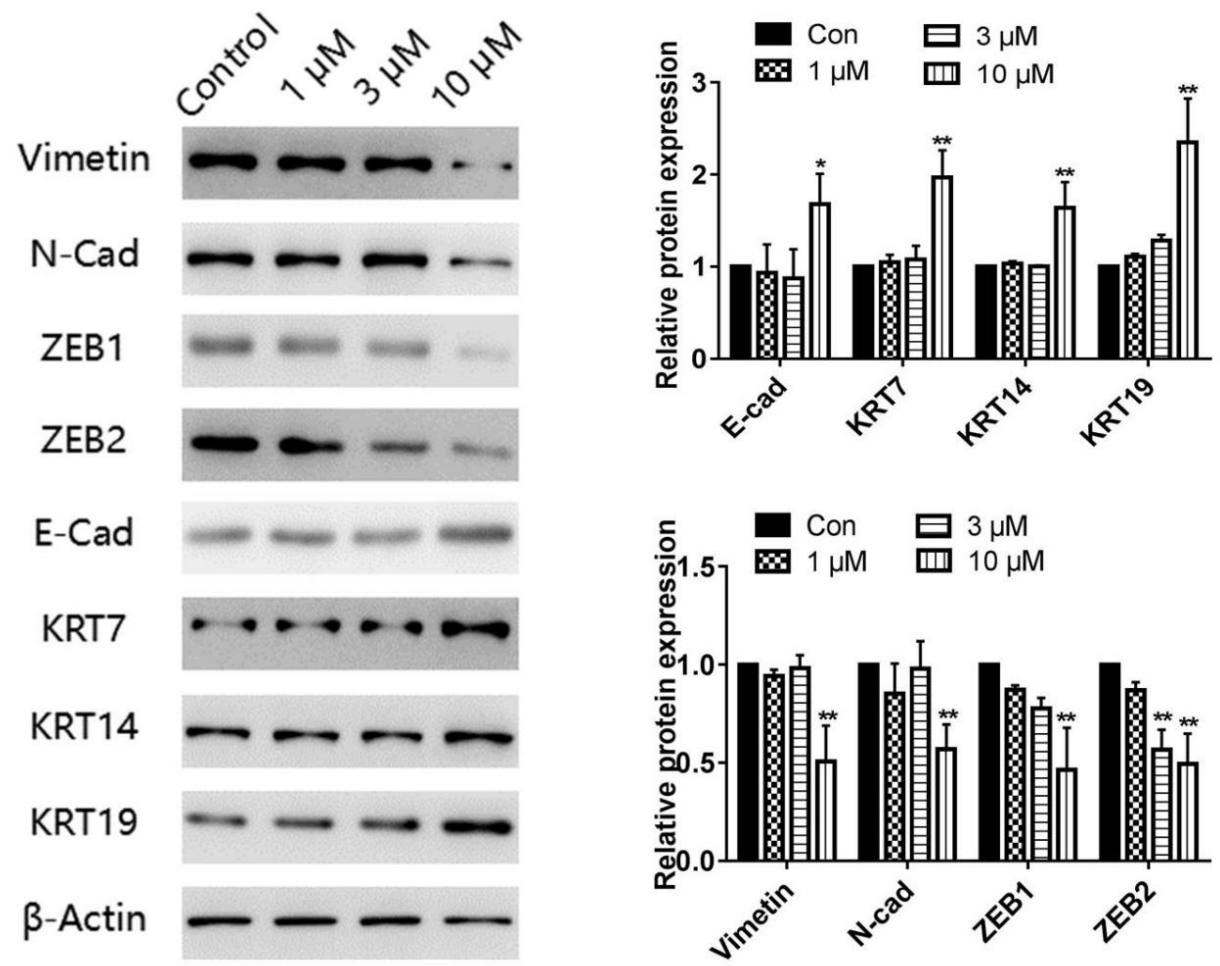

Figure 6: Effect of AA on EMT-related proteins expression. Optimal density was determined and quantified using ImageJ software. Note: Con = control group; ${ }^{*} p<0.05 ;{ }^{* *} p<0.01$

\section{Effect of AA on EMT-related proteins expression}

EMT-related proteins expression was determined via Western blot. As shown in Figure 6, epithelial markers (E-cad and KRT-7/14/19) were elevated, while mesenchymal markers (vimetin, $\mathrm{N}$-cad and ZEB1/2) were suppressed, indicating the EMT process was significantly suppressed by $A A$ treatment at the concentration of $10 \mu \mathrm{M}$.

\section{DISCUSSION}

As a highly metastatic disease, patients with a stage III/IV ovarian cancer have quite dismal prognosis. Therefore, earlier diagnosis, as well as blocking of metastasis is the main striving direction for both basic and clinical research. Although the pro-apoptotic and cell cycle arrest effects on ovarian cancer cells have been reported recently [12], our present study, for the first time, demonstrated that $\mathrm{AA}$, working at a relative low concentration $(10 \mu \mathrm{M})$, could inhibit the metastatic malignant behavior of human ovarian cancer cell line SKOV-3. Moreover, this suppressive effect might be related to EMT inhibition. 
With the application of trans-vaginal ultrasound and cancer antigen (CA) 125 monitoring [15], and later human epididymis protein 4 plus CA125 [16] and serial CA125 measurements [17], doctors and researchers have been trying their efforts to diagnose more patients with pre-clinical and early stage ovarian cancers. However, due to non-specific symptoms as bloating and pelvic pain, there was usually a four to six months' delay from symptom onset to diagnosis $[18,19]$. As a result, distant ovarian cancer accounts for $65 \%$ of diagnosis and $90 \%$ of ovarian cancerrelated death [20].

Therefore, the present study focused on the metastasis of ovarian cancer. We selected a more-metastatic human ovarian cancer cell line SKOV-3 [21] and performed cell viability assay with various $A A$ concentrations $(1,3,10$ and 30 $\mu \mathrm{M})$. The result is comparable to published data on ovarian cancer cell lines [12] and other tumor cells $[11,7,10]$, that $A A(30 \mu \mathrm{M}$ and above) has a definite pro-apoptotic effect. In our present study, we deliberately used lower AA concentrations in the following assays to testify the inhibitory effect on ovarian cancer metastasis. As lower AA concentrations do not show effects on cell growth, the cells on the lower side of the membrane are exactly the cells migrated or invaded. Transwell insert is frequently used in cell migration and invasion assays, with Matrigelcoated membrane mimicking the extracellular matrix. As evidenced by cell migration and invasion assays, AA $(10 \mu \mathrm{M})$ could significantly attenuate the malignant invasiveness of SKOV-3 cells.

Besides the normal metastatic pattern of intravasation and extravasation, the mainstream hypothesis suggested a passive dissemination of detached ovarian cancer cells via peritoneal circulation [22]. EMT plays a pivotal role in both passive and hematogenous routes. EMT, by definition, is a cellular process that epithelial cells (SKOV-3 cells) lose their cell polarity and further cell-cell adhesion, turning to a more elongated morphology (mesenchymal phenotype) with enhanced metastatic properties [23]. Therefore, immunofluorescence staining assay was performed to observe the effect of AA on the EMT process of SKOV-3 cells. As a metastatic ovarian cancer cell line, SKOV-3 cell in the control group exhibited a more mesenchymal phenotype with elongated morphology and Factin stain, which suggested an EMT was taking place. However, after incubation with AA $(10 \mu \mathrm{M})$ for $48 \mathrm{~h}$, EMT was greatly inhibited as cells were of a round morphology with wide range stain of cytokeratin.
Various signaling pathways, including TGF, FGF, PDGF, Wnt and Notch, are involved in this complicated while precisely regulated process [24]. Among them, E-cadherin and $\mathrm{N}$-cadherin play a prominent role. Loss of E-cadherin and gain of $\mathrm{N}$-cadherin is identified as a key event in EMT and thus cancer progression. AA $(10 \mu \mathrm{M})$ treatment could reverse the EMT process of SKOV-3 cells, as exhibited by less $\mathrm{N}$-cadherin while more E-cadherin expression, both at mRNA and protein levels. More EMT-related genes and proteins expressions including vimetin, ZEB1/2 and keratin 7/14/19 were observed in our present study, which further support our hypothesis that $A A$ attenuates the metastatic behavior of SKOV-3 cells through EMT suppression. Further investigations on underlying mechanisms and specific signaling pathways are warranted.

\section{CONCLUSION}

This study reported, for the first time, that $A A$ inhibits the metastatic malignant behavior of human ovarian cancer cell line SKOV-3 at a relative low concentration, and possibly via EMT suppression, and thus, is a potential therapeutic agent for ovarian cancer management.

\section{DECLARATIONS}

\section{Acknowledgement}

None declared.

\section{Conflict of Interest}

No conflict of interest associated with this work.

\section{Contribution of Authors}

The authors declare that this work was done by the authors named in this article and all liabilities pertaining to claims relating to the content of this article will be borne by them.

\section{Open Access}

This is an Open Access article that uses a funding model which does not charge readers or their institutions for access and distributed under the terms of the Creative Commons Attribution License (http://creativecommons.org/licenses/by/ 4.0) and the Budapest Open Access Initiative (http://www.budapestopenaccessinitiative.org/rea d), which permit unrestricted use, distribution, and reproduction in any medium, provided the original work is properly credited. 


\section{REFERENCES}

1. Siegel RL, Miller KD, Jemal A. Cancer statistics, 2016. CA Cancer J Clin 2016; 66: 7-30.

2. Sopik V, lqbal J, Rosen B, Narod SA. Why have ovarian cancer mortality rates declined? Part I. Incidence. Gynecol Oncol 2015; 138: 741-749.

3. Pujade-Lauraine E, Hilpert $F$, Weber $B$, Reuss A, Poveda $A$, Kristensen $G$, Sorio $R$, Vergote $I$, Witteveen $P$, Bamias $A$, et al. Bevacizumab combined with chemotherapy for platinum-resistant recurrent ovarian cancer: The AURELIA open-label randomized phase III trial. J Clin Oncol 2014; 32: 1302-1308.

4. Ledermann J, Harter $P$, Gourley $C$, Friedlander $M$, Vergote I, Rustin G, Scott CL, Meier W, ShapiraFrommer $R$, Safra $T$, et al. Olaparib maintenance therapy in patients with platinum-sensitive relapsed serous ovarian cancer: a preplanned retrospective analysis of outcomes by BRCA status in a randomised phase 2 trial. Lancet Oncol 2014; 15:852-861.

5. Tang $X L$, Yang $X Y$, Jung HJ, Kim SY, Jung SY, Choi DY, Park, WC, Park H. Asiatic acid induces colon cancer cell growth inhibition and apoptosis through mitochondrial death cascade. Biol Pharm Bull 2009; 32: 1399-1405.

6. Hsu YL, Kuo PL, Lin LT, Lin CC. Asiatic acid, a triterpene, induces apoptosis and cell cycle arrest through activation of extracellular signal-regulated kinase and p38 mitogen-activated protein kinase pathways in human breast cancer cells. J Pharmacol Exp Ther 2005; 313: 333-344.

7. Park BC, Bosire KO, Lee ES, Lee YS, Kim JA. Asiatic acid induces apoptosis in SK-MEL-2 human melanoma cells. Cancer Lett 2005; 218: 81-90.

8. Kavitha CV, Jain AK, Agarwal C, Pierce A, Keating A, Huber KM, Serkova NJ, Wempe MF, Agarwal R, Deep G. Asiatic acid induces endoplasmic reticulum stress and apoptotic death in glioblastoma multiforme cells both in vitro and in vivo. Mol Carcinog 2015; 54: 1417 1429.

9. Cho CW, Choi DS, Cardone MH, Kim CW, Sinskey AJ, Rha C. Glioblastoma cell death induced by asiatic acid. Cell Biol Toxicol 2006; 22: 393-408.

10. Zhang J, Ai L, Lv T, Jiang X, Liu F. Asiatic acid, a triterpene, inhibits cell proliferation through regulating the expression of focal adhesion kinase in multiple myeloma cells. Oncol Lett 2013; 6: 1762-1766.

11. Lee YS, Jin DQ, Kwon EJ, Park SH, Lee ES, Jeong TC, Nam DH, Huh K, Kim JA. Asiatic acid, a triterpene, induces apoptosis through intracellular $\mathrm{Ca} 2+$ release and enhanced expression of p53 in HepG2 human hepatoma cells. Cancer Lett 2002; 186: 83-91.

12. Ren L, Cao QX, Zhai FR, Yang SQ, Zhang $H X$. Asiatic acid exerts anticancer potential in human ovarian cancer cells via suppression of PI3K/Akt/mTOR signalling. Pharm Biol 2016; 54: 2377-2382.
13. McGrail DJ, Kieu QM, Dawson MR. The malignancy of metastatic ovarian cancer cells is increased on soft matrices through a mechanosensitive Rho-ROCK pathway. J Cell Sci 2014; 127: 2621-2626.

14. Bian D, Zhang J, Wu X, Dou Y, Yang Y, Tan Q, Xia Y, Gong Z, Dai $Y$. Asiatic acid isolated from Centella asiatica inhibits TGF-beta1-induced collagen expression in human keloid fibroblasts via PPAR-gamma activation. Int J Biol Sci 2013; 9: 1032-1042.

15. McLaughlin JR, Rosen B, Moody J, Pal T, Fan I, Shaw $P A$, Risch HA, Sellers TA, Sun P, Narod SA. Long-term ovarian cancer survival associated with mutation in BRCA1 or BRCA2. J Natl Cancer Inst 2013; 105: 141148.

16. Karlan BY, Thorpe J, Watabayashi K, Drescher CW, Palomares M, Daly MB, Paley $P$, Hillard $P$, Andersen MR, Anderson G, et al. Use of CA125 and HE4 serum markers to predict ovarian cancer in elevated-risk women. Cancer Epidemiol Biomarkers Prev 2014; 23: 1383-1393.

17. Menon U, Gentry-Maharaj A, Hallett R, Ryan A, Burnell $M$, Sharma A, Lewis S, Davies S, Philpott S, Lopes A, et al. Sensitivity and specificity of multimodal and ultrasound screening for ovarian cancer, and stage distribution of detected cancers: results of the prevalence screen of the UK Collaborative Trial of Ovarian Cancer Screening (UKCTOCS). Lancet Oncol 2009; 10: 327-340.

18. Wikborn C, Pettersson F, Moberg PJ. Delay in diagnosis of epithelial ovarian cancer. Int J Gynaecol Obstet 1996; 52: 263-267.

19. Nagle CM, Francis JE, Nelson AE, Zorbas H, Luxford K, de Fazio A, Fereday S, Bowtell DD, Green AC, Webb $P M$. Reducing time to diagnosis does not improve outcomes for women with symptomatic ovarian cancer: a report from the Australian Ovarian Cancer Study Group. J Clin Oncol 2011; 29:2253-2258.

20. Sopik V, lqbal J, Rosen B, Narod SA. Why have ovarian cancer mortality rates declined? Part II. Case-fatality. Gynecol Oncol 2015; 138: 750-756.

21. Jacob F, Nixdorf S, Hacker NF, Heinzelmann-Schwarz VA. Reliable in vitro studies require appropriate ovarian cancer cell lines. J Ovarian Res 2014; 7: 60.

22. Yeung $T L$, Leung $C S$, Yip KP, Au Yeung CL, Wong ST, Mok SC. Cellular and molecular processes in ovarian cancer metastasis. A Review in the Theme: Cell and Molecular Processes in Cancer Metastasis. Am J Physiol Cell Physiol 2015; 309: C444-456.

23. Koutsaki M, Spandidos DA, Zaravinos A. Epithelialmesenchymal transition-associated miRNAs in ovarian carcinoma, with highlight on the miR-200 family: prognostic value and prospective role in ovarian cancer therapeutics. Cancer Lett 2014; 351: 173-181.

24. Moustakas A, Heldin CH. Signaling networks guiding epithelial-mesenchymal transitions during embryogenesis and cancer progression. Cancer Sci 2007; 98: 1512-1520. 